\title{
The Effect of Realistic Mathematical Approaches and Learning Independence on Students' Mathematical Communication Ability SD Negeri Cot Meuraja
}

\author{
Herlin Fitria $^{1}$, Edy Surya ${ }^{2}$, Naeklan Simbolon ${ }^{3}$ \\ ${ }^{1}$ Postgraduate Program in Universitas Negeri Medan, Indonesia \\ ${ }^{2,3}$ Universitas Negeri Medan, Indonesia \\ herlinfitriaumar@gmail.com
}

\begin{abstract}
This study aims to determine: (1) To determine the differences in mathematical communication of students who are taught using a realistic mathematical approach compared to conventional approaches; (2) To determine the differences in mathematical communication skills of students who have high learning independence compared to students who have low learning independence; and (3) To determine the interaction between realistic mathematical approaches and independent learning on students' mathematical communication skills. This research was conducted at SD Negeri Cot Meuraja. The research method used is quantitative with a quasi-experimental research type. Data collection techniques used questionnaires and tests. The data analysis technique in this study used the Two Way Anova test. The results showed that: (1) The mathematical communication skills of students who are taught with a realistic mathematical approach are higher than conventional approaches $($ Fcount $=23.476$ and sig. 0.000> 0.05); (2) The mathematical communication skills of students who have high learning independence are higher than students who have low learning independence (Fcount $=7.673$ and sig. 0.008>0.05).
\end{abstract}

Keywords

realistic mathematics; independent learning; mathematical communication

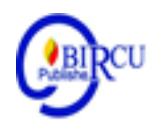

\section{Introduction}

Mathematics learning objectives formulated by the National Council of Teachers of Mathematics Fahradina (2014: 55) are: (1) learning to communicate (mathematical comminication), (2) learning to reason (mathematical reasoning), (3) learning to solve problems (mathematical problem solving), (4) learning to link ideas (mathematical connections), (5) forming positive attitudes toward mathematics. Irhamna (2020) states that Mathematics is a universal science. Mathematics is also seen as the queen of science.

From the objectives of learning mathematics above, it appears that one of the aspects emphasized in the 2013 curriculum is improving students' mathematical communication skills. Mathematical communication is very important for students. This is contained in the National Council of Teachers of Mathematics which explains that communication is an essential part of mathematics and mathematics education. This opinion suggests the importance of communication in mathematics learning.

The facts in the field show that the students 'mathematical communication skills are still low, the teacher is not able to improve mathematical communication so that the students' mathematical communication skills are only in short verbal answers to various statements submitted by the teacher. According to research conducted by Sokoine (2015: 
499), the communication skills program felt by most of the course respondents is very important for the acquisition of communication skills needed in their academic life. So in the process of learning mathematics it is very important for students to have the ability to communicate mathematically. Learning communication in mathematics fosters interaction and expresses ideas in the classroom because students learn in an active atmosphere. The same is the case with research conducted by (Hernawati, Mahmudi, Lestari, 2013) which states that in reality students' mathematical communication skills are still low. This is due to the lack of student activity where they have not carried out activities that are maximally meaningful such as discovering mathematical concepts and principles, exploring concepts, and analyzing mathematical problems.

One of the ways that teachers can use toimproving mathematical communication and student learning independence is to use the Realistic Mathematical Approach. The development of a realistic mathematics approach actually combines views of what mathematics is, how students learn mathematics and how mathematics should be taught (Johar, 2007: 176). Realistic mathematics learning emphasizes the relationship between mathematical concepts that children have in everyday life. Learning using a realistic mathematics approach begins with solving problems that exist around students and is based on the knowledge already possessed by students, so that it is expected to improve mathematical communication skills and student learning independence. In a realistic mathematical approach, mathematics is presented as a process, as a human activity, not as a finished product. Rahmawati (2015: 226) in her journal states that the theory of realistic mathematical approaches is in line with learning theories that are currently developing, such as constructivism and contextual learning. Realistic mathematics approach is a learning theory developed specifically for mathematics. Learning focuses more on learning activities on students and the environment and teaching materials that are arranged in such a way those students are more active in constructing or developing their own acquired knowledge, while teachers act more as facilitators. A realistic mathematics approach can arouse students' enthusiasm because the problems and examples given are real and exist in the real life of students (Ernalita, 2016: 231). 226) in his journal states that the theory of realistic mathematical approaches is in line with currently developing learning theories, such as constructivism and contextual learning. Realistic mathematics approach is a learning theory developed specifically for mathematics. Learning focuses more on learning activities on students and the environment and teaching materials that are arranged in such a way those students are more active in constructing or developing their own acquired knowledge, while teachers act more as facilitators. A realistic mathematics approach can arouse students' enthusiasm because the problems and examples given are real and exist in the real life of students (Ernalita, 2016: 231). 226) in his journal states that the theory of realistic mathematical approaches is in line with currently developing learning theories, such as constructivism and contextual learning. Realistic mathematics approach is a learning theory developed specifically for mathematics. Learning focuses more on learning activities on students and the environment and teaching materials that are arranged in such a way those students are more active in constructing or developing their own acquired knowledge, while teachers act more as facilitators. A realistic mathematics approach can arouse students' enthusiasm because the problems and examples given are real and exist in the real life of students (Ernalita, 2016: 231).

Learning mathematics using a realistic mathematics approach is one of the hopes to strive for the development of knowledge, increase understanding, mastery, mathematical communication and student learning independence. Because learning with a realistic 
approach is designed starting from solving problems around students and based on the knowledge that students already have. The realistic mathematics learning approach can be one of several learning alternatives that can involve students actively, collaborate, discuss, and argue with classmates so that they can find mathematical concepts themselves through presenting problems that are close to student life (Gumanambo, 2016: 144).

\section{Review of Literatures}

\subsection{Definition of a Realistic Mathematical Approach}

Realistic Mathematics Education (RME) is a mathematics learning approach developed by Freudenthal in the Netherlands in 1970. Realistic mathematics is school mathematics which is implemented by placing students' realities and experiences as a starting point for learning. Realistic problems are used as the source of the emergence of mathematical concepts or formal mathematical knowledge. To be able to teach mathematics, a teacher must be able to prepare lesson plans so mathematics lessonscan be received by students (Nasution, 2020).

The realistic mathematics approach is a theory in mathematics education which is based on the idea that mathematics is a human activity and mathematics must be connected significantly to the context of students' daily lives as a source of development and as an area of application of both horizontal and vertical mathematical processes. Realistic mathematics learning begins with real problems, so students can use previous experiences directly. With realistic mathematics learning, students can develop a more complete concept. Then students can also apply the concepts to new fields and the real world.

Anwar (2010) states that the realistic mathematics approach is a mathematics learning approach that tries to use students' experiences and environments as primary teaching aids. In line with that Supinah (2008: 15-16) states that the realistic mathematics approach is a learning theory that has been developed specifically for mathematics.

Based on Some of these opinions can be concluded that the realistic mathematics approach is an approach to learning mathematics that is close to the real life of students as a means of increasing understanding and reasoning power.

\subsection{Definition of Independent Learning}

Independent study does not mean studying alone. Often people confuse self-study as learning alone. Chapter II of Law Number 20 of 2003 concerning the National Education System states that national education functions to develop capabilities and shape a dignified national character and civilization in order to educate the nation's life, aiming at developing the potential of students to become human beings who believe and have faith in God Who The One and Only, have a noble character, are healthy, knowledgeable, capable, creative, independent, and become democratic and responsible citizens. It is clear that the word independency has emerged as one of the goals of our national education. Therefore, the handling requires special attention from all teachers, especially since there is no special subject on independence.

a. Each individual tries to increase the responsibility for making various decisions.

b. Independent learning is seen as a trait that is inherent in every person and learning situation.

c. Learning to be independent does not mean separating yourself from other people.

d. With independent learning, students can transfer their learning outcomes in the form of knowledge and skills into other situations. 
e. Students doing self-study can involve a variety of resources and activities, such as: self-reading, group study, exercises, electronic dialogue, and correspondence activities.

f. The effective role of teachers in independent learning is still possible, such as dialogue with students, finding resources, evaluating results, and providing creative ideas.

g. Several educational institutions are developing independent learning into a more open program (such as the Open University) as an alternative to individual learning and other innovative programs.

From the definition of independent learning above, it can be concluded that independence is the behavior of students in realizing their will or desires in a real way without depending on others, in this case the student is able to do self-study, can determine effective learning methods, is able to carry out tasks - the task of learning well and able to carry out learning activities independently.

\subsection{Mathematical Communication}

When there is a discussion between students, communication skills are very important, where students are expected to be able to state, explain, describe, listen, ask and work together so that they can bring students to a deep understanding of mathematics. Communication skills are seen as the ability of students to communicate the mathematics they have learned as the message content that must be conveyed. According to Wahyudin (2012: 529) communication can support students' learning of new mathematical concepts when they play a role in situations, take, use objects, provide reports and oral explanations, use diagrams, write, and use symbols. -mathematical symbols.

Another definition of mathematical communication put forward by Romberg and Chair (Sumarmo, 2005: 22) is: connecting real objects, pictures, and diagrams into mathematical ideas; explain ideas, situations and mathematical relations orally or in writing with real objects, pictures, graphics and algebra; express everyday events in language or mathematical symbols; listening, discussing, and writing about mathematics; reading with the understanding of a written mathematical presentation, making conjectures, constructing arguments, formulating definitions and generalizations; explain and make questions about mathematics that have been learned.

Indicators of students' ability in mathematics communication in mathematics learning according to NCTM (1989: 214) can be seen from:

a. Ability to express mathematical ideas through oral, written, and demonstrate and describe them visually.

b. Ability to understand, interprets, and evaluates mathematical ideas both orally, in writing, and in other visual forms.

c. Ability to use terms, mathematical notations and structures to present ideas and describe relationships with situation models.

Broadly speaking, according to Nurahman (2011: 107) it can be concluded that mathematical communication consists of oral and written communication. In this study, oral communication can occur in group discussion activities. Whereas written communication can be grouped into three, namely (1) explaining an idea or situation from a picture or graphic in your own words in writing (writing), (2) stating a situation with a picture or graphic (drawing) and (3) expressing a situation in the form of a mathematical model (mathematical expression). 


\section{Research Methods}

This research was conducted at SD Negeri Cot Meuraja. This research was conducted in the even semester starting from January to February, 2019/2020 school year. The population in this study were all fourth grade students of SD Negeri Cot Meuraja for the 2019/2020 academic year, totaling 50 people who were distributed in two classes, namely class IV-A with 25 students and VI-B with 25 students. Using total sampling, that is, all populations are used as samples. Class IV-A is used as experimental class I which is taught using Realistic Mathemetics learning and class IV-B is used as control class which is taught using conventional learning approaches. This research uses a quantitative approach and this type of research is pseudo experiment. The research design used was a quasy experiment with 2 factorialsx 2 with 2 -way analysis of variance (ANOVA) techniques. The tool used to collect data to determine the level of mathematical communication skills of students is a description test. Measuring students' learning independence in the form of a questionnaire.

The question instrument was validated by statistical tests, carried out by calculating the validity, reliability, difficulty level, and distinguishing power so that the instrument was valid. The data that has been collected will be analyzed descriptively and inferentially. Descriptive statistical data is needed to find the mean, median, standard deviation, variance, range, frequency of graph data and other information using the SPSS 20.0 program. Before the data is analyzed inferentially, the data must be subjected to a prerequisite test in terms of normality and homogeneity.

Furthermore, testing the hypothesis aims to prove the truth of the research hypothesis. To test the hypothesis, a two-way analysis of variance (ANOVA) test was used with the help of SPSS 20.0.The statistical model of this research experiment according to Syahputra (2016: 169). Testing criteria,If F0> Ftable at the selected significant level with the $\mathrm{db}$ of the numerator is the appropriate $\mathrm{db}$, then $\mathrm{HO}$ is rejected, so it can be concluded that there is a difference in the average increase between the groups tested, on the contrary for $\mathrm{F} 0 \leq$ Ftable, then $\mathrm{H} 0$ is accepted. For two-way ANOVA, the first step is to test the statistical hypothesis of the interaction effect, namely F0 (AB). If F0 (AB) $\leq$ Ftable or H0 is accepted which means there is no interaction effect, then the main effect hypothesis test is carried out, namely the F0 (A) test to study the average difference between A. Conversely, if $\mathrm{F} 0(\mathrm{AB})>$ Ftable or $\mathrm{H} 0$ is rejected, meaning that there is a significant interaction effect, so the consequence must be a simple effect test.

\section{Discussion}

\subsection{Description of Data}

\section{a. Pre-Test of Students' Mathematical Communication Ability in Experiment Class}

The lowest score obtained by the students was 45 , while the highest score was 75 with an average value of 60.40 ; the median is 60.00; and mode namely 60; standard deviation of 7.06; and a variant of 49.83. Furthermore, the frequency distribution of the data can be described in the following histogram form. 


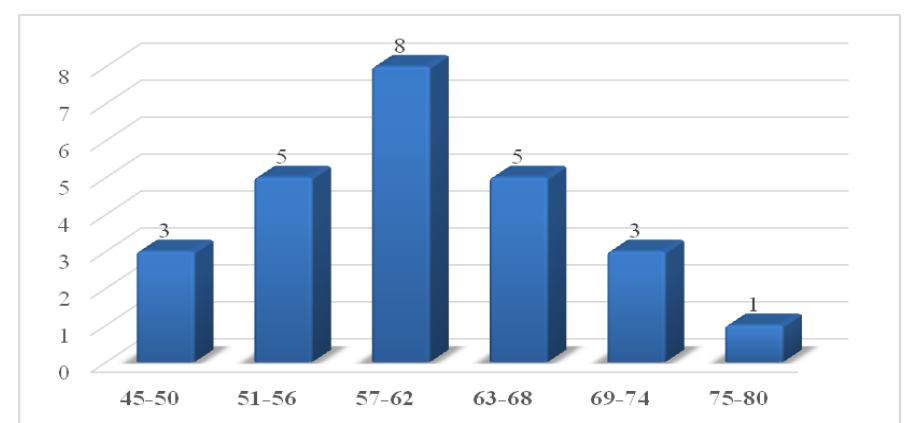

Figure 1. Pre-Test Histograms of Students' Mathematical Communication Ability in Experiment Class

Based on the histogram, it can be seen that the pre-test results of the experimental class with the highest number of frequencies are in the 57-62 interval class, while the least number of frequencies is in the 75-80 interval class.

\section{b. Pre-Test Mathematical Communication Skills for Control Class Students}

The lowest score obtained by the students was 40 , while the highest score was 80 with the average score obtained was 59.60; the median is 60.00; and mode namely 65; standard deviation of 10.20; and a variant of 104.00. Students' mathematical communication skills in the control class with the highest number of frequencies are in the 54-60 interval class, while the least frequency is in the 75-81 interval class.

\section{c. Description of Independent Learning Experiment Class Students}

In addition to giving pre-test to students before treatment, the study also looked at students' early learning independence which was then divided into 2 groups, namely a group of students who had high learning independence and a group of students who had low learning independence. The following shows the frequency distribution of students' independent learning in the experimental class.

Table 1. Frequency Distribution of Independent Learning Students in the Experiment Class

\begin{tabular}{|c|c|c|c|c|c|c|}
\hline \multicolumn{2}{|c|}{ Independent Learning High } & \multicolumn{3}{c|}{ Independent Learning Low } \\
\hline Interval & Frequency & Percentage & Interval & Frequency & Percentage \\
\hline $72-77$ & 2 & $17 \%$ & $51-53$ & 2 & $13 \%$ \\
\hline $78-83$ & 3 & $25 \%$ & $54-56$ & 4 & $27 \%$ \\
\hline $84-89$ & 3 & $25 \%$ & $57-59$ & 7 & $47 \%$ \\
\hline $90-95$ & 2 & $17 \%$ & $60-62$ & 2 & $13 \%$ \\
\hline Total & $\mathbf{1 0}$ & $\mathbf{1 0 0 \%}$ & total & $\mathbf{1 5}$ & $\mathbf{1 0 0 \%}$ \\
\hline
\end{tabular}

Based on this table, it can be seen that of the 25 students in the experimental class there are 10 students who have high learning independence and 15 students who have low learning independence.

\section{d. Description of Independent Learning of Control Class Students}

Furthermore, it can be seen the distribution of independent learning in the control class. The following is the frequency distribution of students' independent learning in the control class. 
Table 2. Frequency Distribution of Independent Learning Students in Control Class

\begin{tabular}{|c|c|c|c|c|c|c|}
\hline \multicolumn{2}{|c|}{ Independent Learning High } & \multicolumn{3}{c|}{ Independent Learning Low } \\
\hline Interval & Frequency & Percentage & Interval & Frequency & Percentage \\
\hline $72-77$ & 2 & $15 \%$ & $44-48$ & 2 & $17 \%$ \\
\hline $78-83$ & 4 & $31 \%$ & $49-53$ & 4 & $33 \%$ \\
\hline $84-89$ & 6 & $46 \%$ & $54-58$ & 4 & $33 \%$ \\
\hline $90-95$ & 1 & $8 \%$ & $59-63$ & 2 & $17 \%$ \\
\hline Total & $\mathbf{1 3}$ & $\mathbf{1 0 0 \%}$ & total & $\mathbf{1 2}$ & $\mathbf{1 0 0 \%}$ \\
\hline
\end{tabular}

Based on table It can be seen that of the 25 students in the control class there are 13 students who have high learning independence and 12 students who have low learning independence.

\section{e. Post-test Students' Mathematical Communication Skills Taught with a Realistic Mathematical Approach}

Based on the data obtained and the results of statistical calculations, it is known that the mathematical communication skills of students who are taught with a realistic mathematical approach get the lowest score, namely 73 , and the highest score, namely 100 , with an average of 86.17; the variant is 57.47 and the standard deviation is 7.58 . The frequency distribution of students' mathematical communication skills scores taught using a realistic mathematical approach is presented in the following table.

Table 3. Frequency Distribution of Students' Mathematical Communication Abilities Taught with Realistic Mathematical Approaches

\begin{tabular}{|c||c||c|}
\hline Interval & Frequency & Percentage (\%) \\
\hline $73-77$ & 3 & $11 \%$ \\
\hline $78-82$ & 5 & $19 \%$ \\
\hline $83-87$ & 8 & $30 \%$ \\
\hline $88-92$ & 0 & $0 \%$ \\
\hline $93-97$ & 8 & $30 \%$ \\
\hline $98-102$ & 1 & $4 \%$ \\
\hline total & $\mathbf{2 5}$ & $\mathbf{1 0 0 \%}$ \\
\hline
\end{tabular}

From the table, the frequency distribution of students 'mathematical communication skills taught with a realistic mathematical approach can be seen that 8 students or $32 \%$ of 25 students have mathematical communication skills below the average of 82 (post-test average results of students' mathematical communication skills). experimental class and control class). Meanwhile, 17 or $68 \%$ of other students have mathematical communication skills above average.

\section{f. Post-test Students' Mathematical Communication Skills Taught with Conventional Approaches}

From the data obtained and the results of statistical calculations, it is known that the mathematical communication skills of students who are taught using the conventional approach get the lowest score, namely 63, and the highest score, namely 93 , with an average of 78.40; the variant is 60.30 and the standard deviation is 7.77. The frequency distribution of students' mathematical communication skills scores taught by conventional approaches is presented in the following table. 
Table 4. Frequency Distribution of Students' Mathematical Communication Ability Taught with Conventional Approaches

\begin{tabular}{|c||c||c|}
\hline Interval & Frequency & Percentage (\%) \\
\hline $63-68$ & 3 & $11 \%$ \\
\hline $69-74$ & 5 & $19 \%$ \\
\hline $75-79$ & 4 & $15 \%$ \\
\hline $80-84$ & 9 & $33 \%$ \\
\hline $85-89$ & 2 & $7 \%$ \\
\hline $90-94$ & 2 & $7 \%$ \\
\hline total & $\mathbf{2 5}$ & $\mathbf{1 0 0 \%}$ \\
\hline
\end{tabular}

From the table, the frequency distribution of students' mathematical communication skills taught by conventional approaches can be seen that 14 students or $56 \%$ of 25 students have mathematical communication skills below average. Meanwhile, 11 or $44 \%$ of other students have mathematical communication skills above average.

\section{g. Students' Mathematical Communication Skills with High Learning Independence}

From the data obtained from the results of statistical calculations it is known that the mathematical communication skills of students who have high learning independence get the lowest score, namely 57, and the highest score is 100 , with an average of 84.48 ; the variant is 92.08 and the standard deviation is 9.60. The frequency distribution of students' mathematical communication skills who have high learning independence can be seen that 23 students who have high learning independence from the total sample of 50 students. Based on table 4.7 it can be seen that 12 students or $52 \%$ of 23 students have mathematical communication skills below average. Meanwhile, 11 or $48 \%$ of other students have mathematical communication skills above average.

\section{h. The Mathematical Communication Ability of Students with Low Learning Independence}

From the data obtained and the results of statistical calculations it is known that the mathematical communication skills of students who have low learning independence get the lowest score, namely 63, and the highest score, namely 93, with an average of 80.42; variants of 51.98 and a standard deviation of 7.21. The frequency distribution of students' mathematical communication ability scores who have low learning independence can be seen that 27 students who have low learning independence from the total sample. Based on table 4.8 , it can be seen that 14 students or $52 \%$ of 27 students have mathematical communication skills below average. As many as 13 or $48 \%$ of other students have mathematical communication skills above average.

\section{i. Students' Mathematical Communication Skills Taught with Realistic Mathematical} Approaches and Have High Learning Independence

Based on the data obtained and the results of statistical calculations, it is known that the mathematical communication skills of students who are taught with realistic mathematical approaches and have high learning independence get the lowest score, namely 87 , and the highest score, namely 100 , with an average of 93.30 ; the variance is 16.83 and the standard deviation is 4.10. The frequency distribution of students' mathematical communication skills scores who are taught with a realistic mathematical approach and have high learning independence is presented in the following table. 
Table 5. Frequency Distribution of Students' Mathematical Communication Ability Taught with a Realistic Mathematical Approach and Have High Learning Independence

\begin{tabular}{|c||c||c||}
\hline Interval & Frequency & Percentage (\%) \\
\hline $87-90$ & 2 & $20 \%$ \\
\hline $91-94$ & 5 & $50 \%$ \\
\hline $95-98$ & 2 & $20 \%$ \\
\hline $99-102$ & 1 & $10 \%$ \\
\hline total & 10 & $100 \%$ \\
\hline
\end{tabular}

From this table, it can be seen that 10 students out of 25 students in the experimental class have high learning independence. Based on statistical calculations it can be seen that all students who are taught with realistic mathematical approaches and have high learning independence have mathematical communication skills above average.

\section{j. Students' Mathematical Communication Skills Taught with Realistic Mathematical} Approaches and Have Low Learning Independence

From the data obtained and the results of statistical calculations it is known that the mathematical communication skills of students who are taught with a realistic mathematical approach and have low learning independence get the lowest score, namely 73, and the highest score, namely 93, with an average of 93.30; the variance is 16.83 and the standard deviation is 4.10 . The frequency distribution of students' mathematical communication skills scores who are taught with a realistic mathematical approach and have low learning independence, it can be seen that 12 students or $80 \%$ of 15 students have mathematical communication skills below average. Meanwhile, 3 or $20 \%$ of other students have mathematical communication skills above average.

\section{k. Students' Mathematical Communication Skills Taught with Conventional} Approaches and Have High Learning Independence

From the data obtained and the results of statistical calculations it is known that the mathematical communication skills of students who are taught with conventional approaches and have high learning independence get the lowest score, namely 67, and the highest score, namely 87, with an average of 77.69; variants of 41.45 and standard deviation of 6.44. The frequency distribution of students' mathematical communication skills scores who are taught using a conventional approach and have high learning independence is presented in the following table.

Table 6. Frequency Distribution of Students' Mathematical Communication Abilities Taught with Conventional Approaches and Have High Learning Independence

\begin{tabular}{||c||c||c||}
\hline Interval & Frequency & Percentage (\%) \\
\hline $67-71$ & 3 & $23 \%$ \\
\hline $72-76$ & 2 & $15 \%$ \\
\hline $77-81$ & 3 & $23 \%$ \\
\hline $82-86$ & 4 & $31 \%$ \\
\hline $87-91$ & 1 & $8 \%$ \\
\hline total & 13 & $100 \%$ \\
\hline
\end{tabular}

From the table, it is known that 13 of the 25 students in the control class have high learning independence. Based on statistical calculations it can also be seen that 8 students or $62 \%$ of the 13 students have mathematical communication skills below average. 
Meanwhile, 5 or $38 \%$ of other students have mathematical communication skills above average.

\section{l. Students' Mathematical Communication Skills Taught with Conventional} Approaches and Have Low Learning Independence

From the data obtained and the results of statistical calculations it is known that the mathematical communication skills of students who are taught with conventional approaches and have low learning independence get the lowest score, namely 63, and the highest score, namely 93, with an average of 79.17; the variant is 85.10 and the standard deviation is 9.23. The frequency distribution of students' mathematical communication skills scores who are taught using conventional approaches and have low learning independence, it can be seen that 12 out of 25 students in the control class have low learning independence. Based on statistical calculations it can also be seen that 9 students or $75 \%$ of the 12 students have mathematical communication skills below average. Meanwhile, 3 or $25 \%$ of other students have mathematical communication skills above average.

\subsection{Data Analysis Testing}

a. Normality Test

The results of the pre-test data normality test of students' mathematical communication skills with the Shapiro-Wilk test obtained a probability value or a significant value of $0.622>0.05$, thus it can be concluded that the pre-test data were normally distributed. The results of the post-test data normality test of students' mathematical communication skills with the Shapiro-Wilk test obtained a probability value or a significant value of $0.378>0.05$, thus it can be concluded that the post-test datadistributed normally.

\section{b. Homogeneity Test}

Homogeneity testing of the pre-test data obtained a probability value or a significant value of $0.52>0.05$, thus it can concluded that the research data group is relatively the same or is homogeneous.

Table 7. Post-test Data Homogeneity Testing

Test of Homogeneity of Variances

Students' Mathematical Communication Skills

\begin{tabular}{|c|c|c|c|}
\hline Levene Statistics & dfl & $\mathrm{df} 2$ & Sig. \\
\hline, 000 & 1 & 48 &, 996 \\
\hline
\end{tabular}

Based on the table above shows that the post-test data homogeneity test obtained a probability value or a significant value of $0.996>0.05$, thus concluded that the research data group based on post-test scores is relatively the same or homogeneous.

\subsection{Testing Hypothesis}

Hypothesis testing requirements for parametric tests have been met, namely group data is normally distributed and has homogeneous variance. Hypothesis testing in this study uses two-way ANOVA with $2 \times 2$ factorial, hypothesis testing is calculated with the help of SPSS version 23. Hypothesis testing data can be seen in the following table: 
Table 8. ANAVA Calculation Results SPSS Output

Tests of Between-Subjects Effects

Dependent Variable: Students' Mathematical Communication Ability

\begin{tabular}{|l|r|r|r|r|r|}
\hline Source & $\begin{array}{c}\text { Type III Sum } \\
\text { of Squares }\end{array}$ & df & Square & F & Sig. \\
\hline Corrected Approach & $1623,503 \mathrm{a}$ & 3 & 541,168 & 12,841 &, 000 \\
Intercept & 336239,807 & 1 & 336239,80 & 7978,54 &, 000 \\
Learning approaches & 989,365 & 1 & 989,365 & 23,476 &, 000 \\
Independent Learning & 323,381 & 1 & 323,381 & 7,673 &, 008 \\
Learning Approach * & 547,982 & 1 & 547,982 & 13,003 &, 001 \\
Learning Independence & 1938,577 & 46 & 42,143 & & \\
Error & 342062,000 & 50 & & & \\
Total & 3562,080 & 49 & & & \\
\hline Corrected Total & & & & & \\
\hline
\end{tabular}

a. $\quad$ R Squared $=, 456$ (Adjusted R Squared $=, 420$ )

Table 9. Comparison of Mathematical Communication Abilities Based on Learning Approaches

\section{Learning Approach}

Dependent Variable: Mathematical Communication Ability

\begin{tabular}{|l|r|r|r|r|}
\hline $\begin{array}{l}\text { Learning } \\
\text { approaches }\end{array}$ & \multicolumn{2}{|c|}{ Mean } & Std. Error & \multicolumn{2}{|c|}{ 95\% Confidence Interval } \\
\hline & \multicolumn{2}{|c|}{} & $\begin{array}{l}\text { Lower } \\
\text { Bound }\end{array}$ & Upper Bound \\
\hline $\begin{array}{l}\text { Realistic } \\
\begin{array}{l}\text { Mathematical } \\
\text { Approach }\end{array}\end{array}$ & 87,383 & 1,325 & 84,716 & 90,051 \\
\hline $\begin{array}{l}\text { Conventional } \\
\text { Approach }\end{array}$ & 78,391 & 1,299 & 75,775 & 81,007 \\
\hline
\end{tabular}

Table 10. Comparison of Mathematical Communication Abilities Based on Learning Independence

Independent Learning

Dependent Variable: Mathematical Communication Ability

\begin{tabular}{|l|l|l|l|l|}
\hline Independent Learning & Mean & Std. Error & \multicolumn{2}{|c|}{$95 \%$ Confidence Interval } \\
\hline & & $\begin{array}{l}\text { Lower } \\
\text { Bound }\end{array}$ & Upper Bound \\
\hline
\end{tabular}




\begin{tabular}{|l|r|r|r|r|}
\hline $\begin{array}{l}\text { High Learning } \\
\text { Independence }\end{array}$ & 85,458 & 1,365 & 82,710 & 88,206 \\
\hline $\begin{array}{l}\text { Low Learning } \\
\text { Independence }\end{array}$ & 80,317 & 1,257 & 77,786 & 82,847 \\
\hline
\end{tabular}

Table 11. Comparison of mathematical communication skills based on independent learning

\section{Learning Approach * Learning independence}

Dependent Variable: Mathematical Communication Ability

\begin{tabular}{|l|l|r|r|r|r|}
\hline $\begin{array}{l}\text { Learning } \\
\text { approaches }\end{array}$ & Independent & Mean & Std. Error & \multicolumn{2}{|c|}{$95 \%$ Confidence Interval } \\
\hline $\begin{array}{ll}\text { Realistic } \\
\text { Mathematics }\end{array}$ & $\begin{array}{l}\text { High Learning } \\
\text { Independence }\end{array}$ & 93,300 & 2,053 & 89,168 & 97,432 \\
& $\begin{array}{l}\text { Low Learning } \\
\text { Independence }\end{array}$ & 81,467 & 1,676 & 78,093 & 84,841 \\
\hline Conventional & $\begin{array}{l}\text { High Learning } \\
\text { Independence } \\
\end{array}$ & 77,615 & 1,800 & 73,991 & 81,240 \\
\hline $\begin{array}{l}\text { Low Learning } \\
\text { Independence }\end{array}$ & 79,167 & 1,874 & 75,394 & 82,939 \\
\hline
\end{tabular}

Based on Table 8; Table 9; Table 10; and Table 11. it can be explained about the research hypothesis testing as follows:

\section{First Hypothesis}

Based on the SPSS output in Table 8 regarding mathematical communication skills based on the learning approach, it is found that the value of Fcount $=23,476$ andthe probability value or significant value of the learning approach is $0.000<0.05$. Thus it can be said that there is a significant difference between the average mathematical communication skills of students who are taught with realistic mathematics learning approaches compared to conventional approaches. Furthermore, based on the SPSS output on the comparison of mathematical communication skills based on the learning approach in Table 9, it was found that the average mathematical communication skills of students who were taught using a realistic mathematics learning approach were 87.383. Meanwhile, students' mathematical communication skills taught by conventional approaches amounted to 78.391. This indicates that the average mathematical communication skills of students taught with a realistic mathematics learning approach are higher than the average mathematical communication skills of students taught using conventional approaches. So that the hypothesis testing rejects $\mathrm{Ho}$ and accepts Ha. With the conclusion that the mathematical communication skills of students who are taught with realistic mathematics 
learning approaches are higher than conventional approaches.

2. Second Hypothesis

Based on the SPSS output in Table 8 regarding mathematical communication skills based on independent learning, it is found that the value of Fcount $=7,673$ and value probability or significant value of $0.008<0.05$. Thus it can be said that there is a significant difference between the mathematical communication skills of students who have high learning independence compared to the mathematical communication skills of students who have low learning independence. Furthermore, based on the SPSS output on the comparison of mathematical communication skills based on student learning independence in Table 10. it was found that the mathematical communication skills of students who had high learning independence were 85.458. While the mathematical communication skills of students who have low learning independence amounted to 80.317. This shows that the average mathematical communication ability of students who have high learning independence is higher than the mathematical communication skills of students who have low learning independence. So that the hypothesis testing rejects Ho and accepts Ha. With the conclusion that the mathematical communication skills of students who have high learning independence are higher than students who have low learning independence.

3. Third Hypothesis

Based on the SPSS output in Table 8, it is found that Fcount $=13.003$ and a significant value of 0.001 with $\alpha=0.05$. Then it can be seen that the sig. $0.001<0.05$ so that the hypothesis testing rejects Ho and accepts Ha. With the conclusion that there is an interaction between the learning approach and student learning independence in influencing students' mathematical communication skills.

4. Test Tukey

The explanation is as follows:

1) Based on the results of Tukey's test, it can be concluded that there is a significant difference between the mathematical communication skills of students who are taught with a realistic mathematics approach and have high learning independence compared to the mathematical communication skills of students who are taught with a realistic mathematics approach and have low learning independence (Mean Diff $=11,83$; and significant value $=0.000$ )

2) Based on the results of Tukey's test, it can be concluded that there is a significant difference between the mathematical communication skills of students who are taught with realistic mathematics approaches and have high learning independence compared to the mathematical communication skills of students who are taught with conventional approaches and have high learning independence (Mean Diff $=15.68$; and significant value $=0.000$ ) .

3) Based on the results of Tukey's test, it can be concluded that there is a significant difference between the mathematical communication skills of students who are taught with a realistic mathematics approach and have high learning independence compared to the mathematical communication skills of students who are taught with conventional approaches and have low learning independence (Mean Diff $=14,13$; and the value sig $=0,000$ ). 


\section{Conclusion}

Based on the discussion previously described, several conclusions can be drawn among them as follows:

1. Students' mathematical communication skills taught with realistic mathematical approaches are higher than conventional approaches (Fcount $=23.476$ and sig. $0.000>0.05)$.

2. The mathematical communication skills of students who have high learning independence are higher than students who have low learning independence (Fcount $=7.673$ and sig. $0.008>0.05$ ).

3. There is an interaction between the learning approach and learning independence in influencing students' mathematical communication skills (Fcount $=13.003$ and sig. $0.001>0.05)$.

\section{References}

Anwar, A. (2010). Pendekatan Matematika Realistik: Cara Efektif Meningkatkan Pemahaman Logika Matematika Siswa. Makalah SepNas FKIP UNSYIAH: Banda Aceh.

Ernalita. (2016). Pendekatan Matematika Realistik dengan Pembelajaran Kooperatif Tipe STAD Untuk Meningkatkan Hasil Belajar siswa di Sekolah Dasar. Jurnal Ilmu Pendidikan Sosial, Sains, dan Humaniora, 2 (3).

Fahradina, N. (2014). Peningkatan Kemampuan Komunikasi Matematis dan Kemandirian Belajar Siswa SMP dengan Menggunakan Model Investigasi kelompok. Jurnal Didaktik Matematika, 1 (1): 54-64.

Gumanambo, N., Sukayasa., \& Gandung, S. (2016). Penerapan Pendekatan Matematika Realistik Untuk Meningkatkan Hasil Belajar Siswa Pada Materi Penjumlahan dan Pengurangan Bentuk Aljabar di Kelas VII SMPN 9 Palu. Jurnal Elektronik Pendidikan Matematika Tadulako, 4 (1): 143-155.

Hernawati, K., Mahmudi, A., \& Lestari, H.P. (2013). Pengembangan Perangkat Pembelajaran Geometri Berbasis ICT untuk Meningkatkan Kemampuan Komunikasi Matematis Mahasiswa. Makalah. Seminar Nasional Matematika dan Pendidikan Matematika FMIPA UNY.

Irhamna, Amry, Z., and Syahputra, H. (2020). Contribution of Mathematical Anxiety, Learning Motivation and Self-Confidence to Student's Mathematical Problem Solving. Budapest International Research and Critics in Linguistics and Education (BirLE) Journal Vol 3 (4): 1759-1772.

Johar, R. (2007). Pembelajaran Matematika SD 2. Kerja Sama Universitas Syiah Kuala Banda Aceh dan IAIN Ar Raniry Banda Aceh.

Kurniawati, D. (2010). Upaya Meningkatkan Kemandirian Belajar Siswa dalam Pembelajaran Matematika Melalui Model Kooperatif Learning Kepal Bernomor Berstruktur pada Siswa SMPN 2 Sewon Bantul. Yogyakarta: Skripsi FMIPA UNY. Tidak dipublikasikan.

Marpaung, R., Syahputra, E. (2016). Student's Mathematics Representation And The alternative Solution. Proceeding og the $1^{\text {st }}$ Annual International seminar on Transformative Education and Educational Leadership (AISTEEL). Vol.1

Nasution, Y.S., Syahputra, E., and Mulyono. (2020). The Development of Learning Instrument Using Problem Based Learning Model to Improve Critical Thinking of 
Junior High School Students. Budapest International Research and Critics in Linguistics and Education (BirLE) Journal Vol 3 (3): 1501-1508.

National Council of Teachers of Mathematics. (1989). Assesment Standar for School Mathematics. USA: The National Council of Teachers of Mathematics, Inc.

Nurahman, I. (2011). Pembelajaran Kooperatif Tipe Team-Accelerated Instruction (TAI) untuk Meningkatkan Kemampuan Penalaran dan Komunikasi Matematis Siswa SMP. Pasundan Journal of Mathematics Education, 1 (1): 96-130.

Rahmawati, D. (2015). Keefektifan Pembelajaran Dengan Pendekatan Pendidikan Matematika Realistik Pada Kemampuan Pemecahan Masalah Pokok Bahasan Segiempat di Mts Negeri 1 Palembang. Jurnal Pendidikan Matematika JPM RAF, 1 (1): 225-238.

Sokoine, S. C. K. (2015). "The Perceived Importance of Communication Skills Courses among University Students: The Case of Two Universities in Tanzania". Jurnal International Journal of Education and Research, 3 (2): 497-508.

Sumarmo, U. (2005). Pembelajaran Matematika Untuk Mendukung Pelaksanaan Kurikulum Tahun 2002 Sekolah Menengah. Makalah pada seminar Pendidikan Matematika di FMIPA Universitas Negeri Gorontalo, Gorontalo.

Supinah. (2008). Pembelajaran Matematika SD dengan Pendekatan Kontekstual dalam Melaksanakan KTSP. Yogyakarta: PPPPTK Matematika.

Wahyudin. (2012). Filsafat dan Model-Model Pembelajaran Matematika. Bandung: Mandiri. 